\section{Magic, Pharaonic Egypt}

KATHARINA ZINN

In the modern mind, magic is often seen as opposite to religion or, at best, an early stage of religion. Magic describes actions or knowledge relating to the supernatural or the demonic, but not the divine. The ancient Egyptians, however, did not perceive it as "black art" or "sorcery," in conflict with "white" or "pure" religion (Ritner 1992: 189-92). It took some time before Western scholars could accept how strongly religion, magic, and the sciences, like medicine, were intertwined in ancient Egypt. Book titles such as "Religion and magic in Ancient Egypt," chosen for an overview of all aspects of ancient Egyptian religions (David 2002), would not have been possible in the early years of Egyptology.

Magic was inherent to overall Egyptian thinking and a regular part of religion at all levels of Egyptian society (Taylor 2001: 186), as is seen by the importance of the native term heka. Heka was a cosmic and divine power existing as a force in the universe, personified as the male anthropomorphic god Heka, who represented the tenth hour of the day and, as such, accompanied the sun god in his day barque (Wilkinson 2003: 83, Te Velde 1970, Ritner 1993: 14-28). Both the concept heka and the deity Heka are attested from the Old Kingdom up to the Coptic period, with the earliest mention of the god in the funerary temple of Sahure (5th Dynasty) and both named in the Pyramid Texts (spells 472 and 539). In funerary papyri, Heka is depicted standing together with MAAT behind the throne of OsIRIS, holding serpent wands (Greenfield Book of the Dead of Nestanebtasheru, sheet 88: black line vignette of deceased before Osiris enthroned on mound). Here he is called pekhty-netjer-nefer - power of the good god. Heka could also be described as the soul or manifestation ( $b a$ ) of Re (Pinch 2006: 10). Another word for magic as the power of god and connected with heka is akhw. This idiom covers the performative character of heka, mainly in the form of verbalized spells.

Magic existed from the first moments of creation, empowering the whole process. Therefore Heka could be seen as one of the creator gods. Another explanation is that heka as power or concept was conceived by the creator god's heart at the beginning of time, enabling him to start the creation process (Ritner 1992: 192). Heka appeared even before the creative word $\mathrm{Hu}$, the first creation of Re-Atum, the creator god; therefore magic was already in the world when the gods and the cosmos were shaped. This primordial aspect is stressed in the Coffin Text spell 648 (Ritner 1993: 17). In the Instruction for king Merikare (First Intermediate period, 10th Dynasty - Herakleopolitan Dynasty), heka is described as given by the creator god to mankind to help fight off enemies and preserve their existence, one argument for the understanding of magic as defensive (Lichtheim 1973: 97-109, especially 106; Pinch 2006: 17; Ritner 1993: 20). Nevertheless, heka was also understood as having destructive potential, as is made clear in the medical Pap. Ebers, where it is said to be necessary to drive heka out of the bodies of patients in order to allow them to recover.

Originally, Heka might have been seen as the "Lord of kas" (the life-force belonging to each person from birth), as mentioned when he addressed the gods of the Egyptian pantheon in the Coffin Text spell 261. This spell explained how to "become the god Heka" and the fact that gods created after him were inferior to him ("Down, you who have come afterward. I am Heka." Ritner 1992: 192). Due to his mighty power, he was feared by other gods (Pyramid Texts 472), who felt threatened by him. This is stated in papyrus Berlin 3048, which could have been a hymn for PTAH (Wolf 1929: 40-1) or a cultic text compiled from many originally independent pieces (Knigge 2006: 163): "Everybody shakes when his [i.e., the creator's] $b a$ comes into being, Heka, who has power over the gods" (P. Berlin 3048, 11.8-9). The $b a$ is a major component of 
human and divine beings, often imperfectly translated as "soul" or "personality," mainly active in the afterlife (Taylor 2001: 20-3). Because of his power, Heka is able to protect Osiris in the underworld, and therefore he played a role in the afterlife. Interestingly, all deities or kings had their own heka, seen as a creative power and part of them, like their names or bodies.

Though Heka was of paramount importance, similar to many other deities representing the cosmos, a regular cult did not develop around him (Wilkinson 2003: 110). However, he was given public recognition in shrines dedicated to him in Lower Egypt and the existence of the title "prophet of Heka" (hem-netjer Heka) indicates priesthood (Pinch 2006: 11). A "Mansion of Heka" was associated with Heliopolis, as well as with the Memphite necropolis (Ritner 1993: 26).

The name Heka may derive from $h w j-k a$, meaning "the one who consecrates spirits/ imagery" and was later explained as "the first work" (TeVelde 1970: 179-80), indicating very complex ideas behind the concept heka. Knowing this, it is clear that heka cannot be in opposition to ancient Egyptian religion, as it is the essence of it and animates each and every aspect of it. Therefore, all rituals and cult activities, all knowledge and wisdom, are based on heka (Ritner 1992: 194). In the Papyrus Westcar, the wise man and magician, Djedi, can heal severed heads and bring injured animals back to life, and he knows the secrets and hidden chambers of тнотн. With his skills and knowledge, he can foresee the future while talking to the king (Berlin 3033: 7,1-9,20: Lichtheim 1975: 217-20). This shows that both skills and knowledge were based on or connected with magic. Only the literate elite had access to magical texts, showing that magic could not have broadly existed outside the elite (and therefore "orthodox") religion. In addition to the sacred, divinatory, and medical texts collected and stored by the libraries, i.e., the Library of the House of Life (per-ankh), magical texts were also found among the records of the administration and temple-cult.
Temple-priests acted locally as magicians, while off-duty from their temple rotation (Ritner 1992: 194). Consequently, private magical practice was quite similar to that of public ceremonies or divine.

Since the private magician and the cultic priest were the same, magical spells and ritual or medical texts were composed, compiled, and used by the same group of professionals (Ritner 1993: 2). Therefore, it becomes even clearer why there was no differentiation between religion, magic, and medicine. Magic in medical treatment was represented by the lion-headed goddess Sekhmet, embodying her malignant power, both dangerous and destructive, as well as her protective and healing abilities. Both aspects are covered by her name, which meant "the female powerful one," and she was seen as a daughter of Re (Wilkinson 2003: 181). Physicians, as priests of Sekhmet, were trained in the House of Life, both in magic and practical medicine (Allen 2005: 11-12). They were skilled in the use of magical spells to empower their diagnosis and prescriptions. Preventive medicine was also primarily based on magic, as the "Amulets of health" tell us (Pinch 2006: 142). Further examples of concern for public health are the temple statues called cippi, featuring Horus on a crocodile. One of the most famous is the so-called Metternich Stela, providing narrative spells that combine the fear of scorpion or snake bites with a description of their healing and a myth of the poisoning of the infant Horus (Pinch 2006: 144-5; Ritner 1993: 34). Working on the associative principle of magic, tools used in medical treatments utilized the symbolic power of amuletic characters. In this way, water poured from a simple libation dish with the hieroglyphs ankh ( $f$ life) and $k a$ (ㄴ) life-force) absorbs life from the symbols on it (Libation dish MMA 19.2.16, 1st Dynasty; Allen 2005: 48-9).

Magic in ancient Egypt covered both what we would describe today as white and black magic (Baines 2006: 1). One of the few examples where Egyptian texts speak of "black magic" is the trial against the plotter in the 
harem conspiracy against Rameses III in the 20th Dynasty (Ritner 1992: 194), where the legal documents dealing with the trial state that one of the conspirators had access to a bad magic text belonging to the king (Pinch 2006: 64). This is more or less the only example of a trial of sorcery in ancient Egypt (Ritner 1993: 13). While the Turin Judicial Papyrus delivers a kind of legal transcript of the trials, Pap. Rollin and Pap. Lee focus on a more detailed description of the plot itself. Pap. Rollin gives an account of the magical practices involved (with a parallel in Pap. Lee 1,4): "It happened because writings were made for enchanting, for banishing, for confusing - because some 'gods' were made into wax and some men (also) - and (furthermore) for enfeebling the $\operatorname{limb}(\mathrm{s})$ of men and these (writings) were placed in the hand of Pay-bak-kamen" (Goedicke 1963: 72). This has been interpreted as a reference to the use of wax figures in the use of magic against other people. The Coffin Texts (CT1, 157a) describe such customs, complete with detailed instructions on how to make wax figures of enemies and which spells to recite. This idea is also expressed in an episode in Pap. Westcar (2,23ff.). Pay-bak-kamen had been identified as a leader of the conspiracy, a fact confirmed by the Turin Judicial Papyrus (IV, 2). However, each text or object used against the king would have been damned in the same way, independent of its magic power.

Coffin Texts (spells 75, 87, and 88) also speak directly of "evil magic" (heka djw), expressing this term from the perspective of the deceased, who wants to escape the malevolent doings (heka djw) of underworld demons or sorcerers, after they refuse to obey these demons (Ritner 1993: 21). This should not be understood as a kind of "black magic." A similar type of hostile magic is mentioned in Dream Books (Pap. Chester Beatty 3, col. 7/18), where a dream of being bitten by a dog would predict the use of magic.

Magic was integrated into all of Egyptian life and was used by members of all classes of society. Magic was connected with myth, used by demons and spirits, and employed by magicians and priests in written form, in the same way as the use of magical techniques, magic figurines, statues, and amulets. Amulets and jewellery made in the shape of or bearing amuletic features functioned on the principle of sympathetic magic, attracting powerful forces to give the wearer of the charm assistance or good luck. Some of these pieces were even regarded as universally potent, like the Sacred eye of Horus (udjat, linked to rebirth), the ankh-sign (symbolizing life), or the djedpillar (connected with the death and resurrection of Osiris) (David 2002: 175-6). Magic was used as a solution for problems in this world (fertility magic; medicine; hostile magic from legal handling of images made out of wax or clay by priests in rites for cursing gods, men, enemies, and demons; love charms (Smither 1941); magical spells to warn off snakes) and in the world of the dead (funerary texts used in the funeral or mummification process; funerary ceremonies where the dead and mourners were linked with the archetypal divine family of Isis, Osiris, Horus, and Nephtys; magic bricks), or the connection of both worlds (protective spells against returning bas and kas of the dead or to fend off the dangerous dead, called mut; Letters to the dead as an appeal for help or accusation of evil behavior against the living) (Pinch 2006). Magical practices comprised circumambulation, spitting, blowing, licking, swallowing, use of images, superposition, trampling, binding, breaking, burning, use of colors (especially red or gold), use of sand, numerology, piercing, burial, and oracular consultation, to mention just a few (Ritner 1993: 1-2).

Magic bricks, an example of funerary and afterlife magic and made of unbaked mud, were placed in tombs during the New Kingdom to protect the deceased from enemies of Osiris. They were placed at the cardinal points and contained amulets (a mummiform figure, a djed-pillar, a jackal, and a torch) to ward off damaging forces that could have entered the burial chamber. Their function was explained in the added speech, taken from spell 151 of the 
Book of the Dead (set of magic bricks of the Chantress of Amun Henutmehyt, BM EA 41544-41547; Taylor 2010: 107, 119; 2001: 207-8). Further examples for safeguarding of the deceased are magical figurines of protective deities, seemingly only used in royal burials, such as BM EA 61283 (human headed) and EA 50699 (hippopotamus-headed). By placing these figurines in the royal tombs, these deities were sent by Osiris to help and protect the king on his journey to the Afterlife (Taylor 2010: 200-1).

Another area underlined by heka was the field of oracles or, as the Egyptians called it, the "miracle" (bjajt). A special example that was part of the regular religious life of the Egyptians from the New Kingdom onwards is the "petitioning of the gods" (peh-netjerw) when, during festivals, common people could ask questions about their fate or seek advice for decision making. These divine decrees were recorded in writing and rolled up and could be worn as amulets (Pinch 2006: 35-37, 117-8).

We have evidence for the performance and use of magic and magical rituals in material culture, but interestingly the artifacts (wands, grain-mummies, amulets) are not described in the formularies and magical texts. Instructions, literature describing (fictional) magical performances, and archaeological evidence show slightly different objects (Dieleman 2008: 19: Centrone 2006: 35), so text and object do not always agree. However, in some cases, we can rely on both groups of sources. Serpent wands are one example. Heka is depicted holding them in the aforementioned sheet 88 of the Book of the Dead of Nestanebtasheru (Pap. BM EA10554/88, 21st Dynasty), suggesting that these wands had an apotropaic connotation. Such serpent wands, made of bronze or copper alloy, have survived, and examples are now in the British Museum, London (early 18th Dynasty; Taylor 2010: 40) and the Fitzwilliam Museum, Cambridge (E.63.1896; Middle Kingdom). Both objects were found as part of funerary equipment: EA 52831 was wrapped in the shroud of a mummy, found in a re-used tomb near Deir
el-Bahari (Asasif). E.63.1896 was found in a late Middle Kingdom tomb (Tomb 5) of a lector priest, below the magazines of the Ramesseum at Thebes, next to a box together with the Ramesseum Papyri, containing magical papyri for healing incantations, together with tales (Eloquent peasant, tale of Sinuhe), hymns, the Dramatic Ramesseum papyrus, and administrative papyri. The lid of the box was inscribed with a jackal sitting on a chest, readable as the title of a priestly magical practitioner: "overseer of secrets" (kheri-seshta, Ritner 1993: 231-2). The tomb also held an ivory herdsman, dolls and human hair, animal figurines, amuletic knives depicting BES and Beset brandishing snakes, as well as a bronze statuette of the goddess Beset holding two cobra serpents, which closely resembles the snake-wands (Ritner 2006: 206). Snake wands in general might represent a goddess called Weret Hekau, the "great of magic." She is usually shown as a cobra and acted as a kind of foster-mother to the divine kings, staying with them as a power present in the imagery of the Pharaonic crowns (Pinch 2006: 11).

SEE ALSO: Atum; Cults: divine, Pharaonic Egypt; Dream books, Pharaonic Egypt; Heliopolis, Ain Shams/Matariya; Ka; Libraries, Pharaonic Egypt; Literacy, Pharaonic Egypt; Literature and poetry, Pharaonic Egypt; Medicine, Pharaonic Egypt; Oracles, Pharaonic Egypt; Re and Re Horakhty; Religion, Pharaonic Egypt.

\section{REFERENCES AND SUGGESTED READINGS}

Allen, J. P. (2005) The art of medicine in Ancient Egypt. New York.

Baines, J. (2006) "Display of magic in Old Kingdom Egypt.” In K. Szpakowska, ed., Through a glass darkly: magic, dreams, and prophecy in ancient Egypt: 1-32. Swansea.

Centrone, M. (2006) "Corn-mummies, amulets of life.” In K. Szpakowska, ed., Through a glass darkly: magic, dreams, and prophecy in ancient Egypt: 33-45. Swansea.

David, R. (2002) Religion and magic in Ancient Egypt. London. 
Dieleman, J. (2008) [online] [Accessed December 23, 2010.] "Review: Through a glass darkly: magic, dreams, and prophecy in ancient Egypt., K. Szpakowska, ed." Aestimatio 5: 15-22. Available from http://www.ircps.org/publications/ aestimatio/pdf/Volume5/2008-01-03_Dieleman. pdf.

Goedicke, H. (1963) "Was magic used in the Harem Conspiracy against Ramesses III?” Journal of Egyptian Archaeology 49: 71-92.

Knigge, C. (2006) Das Lob der Schöpfung: Die Entwicklung ägyptischer Sonnen- und Schöpfungshymnen nach dem Neuen Reich. Freiburg.

Koenig, Y. (1994) Magie et magiciens dans l'Égypte Ancienne. Paris.

Lichtheim, M. (1973) Ancient Egyptian literature, vol. 1: The Old and Middle Kingdom. Berkeley.

Pinch, G. (2006) Magic in Ancient Egypt. London.

Ritner, R. K. (1992) "Egyptian magic: questions of legitimacy, religious orthodoxy and social deviance." In A. B. Lloyd, ed., Studies in pharaonic religion and society in honour of J. Gwyn Griffiths: 189-200. London.

Ritner, R. K. (1993) The mechanics of Ancient Egyptian magical practice. Chicago.

Ritner, R. K. (2006) "And each staff transformed into a snake: the serpent wand in ancient Egypt." In K. Szpakowska, ed., Through a glass darkly: magic, dreams, and prophecy in Ancient Egypt: 205-25. Swansea.

Smither, P. (1941) "A Ramesside love charm." Journal of Egyptian Archaeology 27: 131-2.

Taylor, J. (2001) Death and the afterlife in Ancient Egypt. London.

Taylor, J. (2010) Journey through the afterlife: ancient Egyptian book of the dead. London.

TeVelde, H. (1970) "The God Heka in Egyptian theology." Jaarbericht van het VoorasiatischEgyptisch Genootschap Ex Oriente Lux 21: 175-87.

Wilkinson, R. H. (2003) The complete gods and goddesses of Ancient Egypt. London.

Wolf, W. (1929) "Der Berliner Ptah-Hymnus (P. 3048, II-XII).” Zeitschrift für Ägyptische Sprache und Altertumskunde 64: 17-44. 